\title{
Role of PI3-kinase in Bcl-X induction and apoptosis inhibition mediated by IL-3 or IGF-1 in Baf-3 cells
}

\author{
Yann Leverrier ${ }^{1}$, Joëlle Thomas ${ }^{1}$, Anne-Laure Mathieu ${ }^{1}$, \\ Walter Low ${ }^{2}$, Bariza Blanquier ${ }^{1}$ and Jacqueline Marvel ${ }^{*, 1}$ \\ ${ }^{1}$ Immunologie Cellulaire, Laboratoire de Biologie Moléculaire et Cellulaire, Ecole \\ Normale Supérieure de Lyon CNRS UMR49 INRA LA 913, 46 allée d'Italie, \\ 69364 Lyon cedex 07, France \\ 2 Department of Immunology, University College London, Windeyer Building, \\ 46 Cleveland St, London W1P 6DB, UK \\ * corresponding author: J. Marvel, tel: 3347272 8573; fax: 3347272 8686; \\ e-mail: Jacqueline.Marvel@ens-lyon.fr
}

Received 8.9.98; revised 30.11.98; accepted 17.12.98

Edited by $\mathrm{G}$. Salvesen

\begin{abstract}
In Baf-3 cells, IL-3 and IGF-1 both inhibit cell death. These growth factors act at least on two different pathways involved in the inhibition of apoptosis. They both upregulate $\mathrm{Bcl}-\mathrm{X}$ at the mRNA and protein levels and also activate a pathway which inhibits apoptosis in the absence of protein synthesis. Recently, these two growth factors have been shown to activate the PI3-kinase-AKT pathway which leads to the phosphorylation of the pro-apoptotic $\mathrm{Bcl}-\mathrm{X}_{\mathrm{L}}$ regulator Bad. In this study, we have investigated the role of PI3-kinase in the regulation of $\mathrm{Bcl}-\mathrm{X}$ expression and in the survival of Baf-3 cells. We show that PI3-kinase activation is involved in the upregulation of Bcl-X mRNA induced by both IL-3 and IGF-1. Moreover, PI3-kinase activity is also necessary for inhibition of apoptosis and caspase regulation by IGF-1 but not IL-3.
\end{abstract}

Keywords: apoptosis; IL-3; Bcl-X; caspase

Abbreviations: LY, LY294002; W, wortmannin

\section{Introduction}

Apoptosis is a form of cell death which is regulated and executed by cellular proteins. It plays an essential role during embryonic development and in the establishment of functional nervous and immune systems. ${ }^{1}$ It can also be triggered by various forms of stress or cell injury including those produced by most chemotherapeutic agents. ${ }^{2}$ Three gene families are at the core of apoptosis regulation: the Bcl-2/Ced-9 family, the caspase/ICE/Ced-3 family and the Apaf-1/Ced-4 family. Since Ced-3 was found to be homologous to the mammalian cystein protease interleukine-1-converting enzyme (ICE), a family of at least 11 related cystein proteases have been identified. These proteins have now been renamed caspases. All of them cut their substrates after an aspartic acid and are synthesized as inactive proenzymes containing a prodomain and two enzyme subunits. Activation of these enzymes is dependent on their cleavage after an aspartic acid and results in the cleavage of critical cellular substrates. ${ }^{3,4}$ A number of apoptotic stimuli such as the binding of Fas to Fas-L have now been shown to activate a cascade of caspases. ${ }^{5-8}$ Inhibition of caspase activity inhibits apoptosis in some experimental systems but not others. ${ }^{9,10}$ However, in all systems the appearance of morphological changes associated with apoptosis is affected. Ced-4 and the newly identified Apaf- 1 mammalian homologue form a new family of proteins. ${ }^{11}$ Ced4 interacts directly with Ced-3 and Ced-9 in vivo and it is functionally essential for the activation of Ced-3. ${ }^{12,13}$ Similarly Apaf-1, regulates the activation of caspase-9. ${ }^{14}$

ced-9 is homologous to the mammalian bcl-2 gene, which when overexpressed protects cells from apoptosis induced by a variety of stimuli. A large number of proteins homologous to $\mathrm{Bcl}-2$ have now been identified. Functionally, they fall in two groups: proteins which inhibit apoptosis like $\mathrm{Bcl}-2$ or $\mathrm{Bcl}-\mathrm{X}$ and proteins which induce cell death like Bax, Bak or Bad. A number of recent findings have shed some light on some of the mechanisms by which these proteins may act (reviewed $\mathrm{in}^{15}$ ). $\mathrm{Bcl}-2$ and $\mathrm{Bcl}-\mathrm{X}$ have been shown to form discrete ion channels in synthetic lipid membranes. ${ }^{16,17}$ This property may explain how these proteins participate in the regulation of some cellular events, such as the release of pro-apoptotic proteins from mitochondria, a process which is associated with the onset of apoptosis. ${ }^{18,19}$ Another important property of $\mathrm{Bcl}-2$ family members is their ability to associate with a number of different proteins such as Raf or Ced-4. ${ }^{13,20}$ These interactions play an essential role in the regulation of apoptosis by $\mathrm{Bcl}-2$ family members. For instance, the interaction of $\mathrm{Bcl}-\mathrm{X}$ with $\mathrm{Ced}-4$ or Apaf-1 seems to inhibit the activation of caspases.

Growth factors are essential for survival in a number of systems. They are thought to act by inhibiting the apoptotic machinery which is constitutively expressed in all cells. ${ }^{1}$ IL3 regulates a number of intracellular signal transduction pathways which are potentially involved in the inhibition of apoptosis. IL-3 binding to the IL-3 receptor activates PI3kinase and the protein kinase AKT which have been shown to play a key role in the inhibition of apoptosis by growth factors such as IL-2 or NGF. ${ }^{21,22}$ One of the substrates of AKT is the pro-apoptotic protein Bad. ${ }^{23}$ Upon phosphorylation Bad dissociates from $\mathrm{BCl}-\mathrm{X}_{\mathrm{L}}$ and this promotes $\mathrm{Bcl}-\mathrm{X}_{\mathrm{L}}$ anti-apoptotic activity. IL-3 induces the phosphorylation of Bad and its release in the cytosol where it will bind the protein 14.3.3. ${ }^{24}$ Hence activation of AKT by IL-3 could be the major pathway leading to apoptosis inhibition in Baf-3 cells. However, a number of other pathways activated by IL-3 could also contribute to the inhibition of apoptosis. These include STAT3, atypical PKC, the Ras-Raf-MAPK pathway and a pathway located downstream of Shc but which is different from the Ras pathway. ${ }^{25-29}$ The targets of these different signaling pathways as well as the mechanisms by which they inhibit apoptosis are still 
largely unknown. Some of these pathways such as Ras, MAPK, STAT3 and AKT upregulate the expression of the anti-apoptotic members of the Bcl-2 family of genes. ${ }^{21,26,29}$ However, they could also regulate the anti-apoptotic activity of Bcl-2 family members by for example inducing their phosphorylation.

To determine if the pathways downstream of PI3-kinase activation are the only ones involved in the inhibition of apoptosis by IL-3 or IGF-1, we have measured the inhibition of apoptosis by these growth factors in the presence of PI3-kinase inhibitors. The involvement of PI3kinase activation in the regulation of $\mathrm{Bcl}-\mathrm{X}$ mRNA levels by these growth factors was also studied.

\section{Results}

\section{Induction of Bcl-X by IL-3 or IGF-1 is dependent on PI3-kinase activation}

We have previously shown that IL-3 and IGF- 1 regulate the expression of the $b c l-X$ gene at the RNA and protein level in Baf-3 cells. ${ }^{29}$ To assess the role of PI3-kinase activation in the induction of $\mathrm{Bcl}-\mathrm{X}$ by $\mathrm{IL}-3$ and IGF-1, we have measured the induction of $\mathrm{Bcl}-\mathrm{X}$ mRNA in the presence of the two widely used PI3-kinase inhibitors LY294002 and wortmannin. Baf-3 cells were grown in the absence of IL-3 for $6 \mathrm{~h}$. Concentrations of IL-3 or IGF-1 which corresponded to maximum survival after $20 \mathrm{~h}$ in culture (Figure 1) were then added in the presence or absence of PI3kinase inhibitors and the induction of Bcl-X mRNA was measured after $2 \mathrm{~h}$. These two time points correspond to the maximal reduction or increase in Bcl-X mRNA level following IL-3 removal or re-addition respectively. ${ }^{29}$ Results presented in Figure 2 show that the induction of the $\mathrm{Bcl}-\mathrm{X}$ mRNA by IL-3 or IGF-1 was inhibited by both inhibitors although the strongest effect was observed with LY294002. These results indicate that PI3-kinase activation is involved in the regulation of $b c /-X$ gene expression by both $\mathrm{IL}-3$ and IGF-1.

\section{PI3-kinase activation is necessary for the induction of survival by IGF-1 but not IL-3}

We have previously shown that IL-3 or IGF-1 addition to growth factors starved Baf-3 cells inhibits any further increase in the percentage of apoptotic cells. This process is rapid and independent of $\mathrm{Bcl}-\mathrm{X}$ or other protein synthesis indicating some post-translational modifications. ${ }^{29}$ In order to determine if PI3-kinase signals are responsible for protein synthesis independent survival of Baf-3 cells treated with IL-3 or IGF-1, we have measured cell survival induced by these growth factors in the presence of the PI3-kinase inhibitor LY294002. Data presented in Figure $3 \mathrm{~B}$ show that in the presence of LY294002, the survival of Baf-3 cells induced by IGF-1 was reduced. Indeed more than $70 \%$ inhibition of IGF-1 induced Baf-3 survival was observed when $50 \mu \mathrm{M}$ of LY294002 was used (Figure 3C). These results confirm that $\mathrm{PI} 3$-kinase activation is a major survival pathway activated by IGF-1. ${ }^{30,31}$ In contrast, the survival of Baf-3

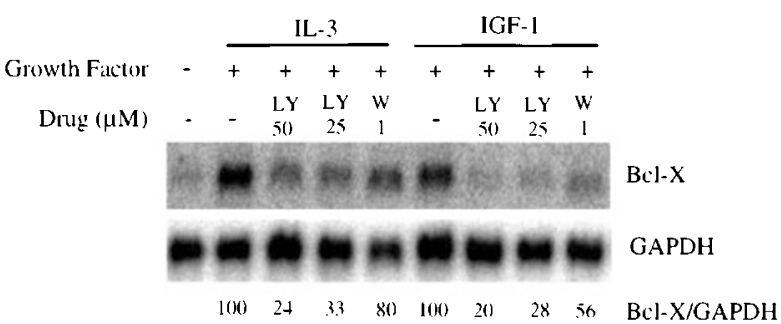

Figure 2 Induction of $\mathrm{Bcl}-\mathrm{X}$ by IL-3 and IGF-1 is dependent on PI3-kinase activation. Baf- 3 cells were starved of IL-3 for $6 \mathrm{~h}$ then re-stimulated with IL-3 $(1 \mathrm{U} / \mathrm{ml})$ or IGF-1 $(300 \mathrm{ng} / \mathrm{ml})$ in the presence of LY294002 (LY) or wortmannin (W). Cells were pre-incubated with LY294002 and wortmannin 15 min before addition of growth factors. After $2 \mathrm{~h}$ of restimulation, cells were lysed for RNA extraction. Ten $\mu \mathrm{g}$ of total RNA was loaded on the gel. Northern blots were hybridized with the Bcl-X and GAPDH probes. The band density ratio Bcl-X/ GAPDH was defined as 100 in Baf-3 cells stimulated with growth factors and the relative ratios were calculated from this
A

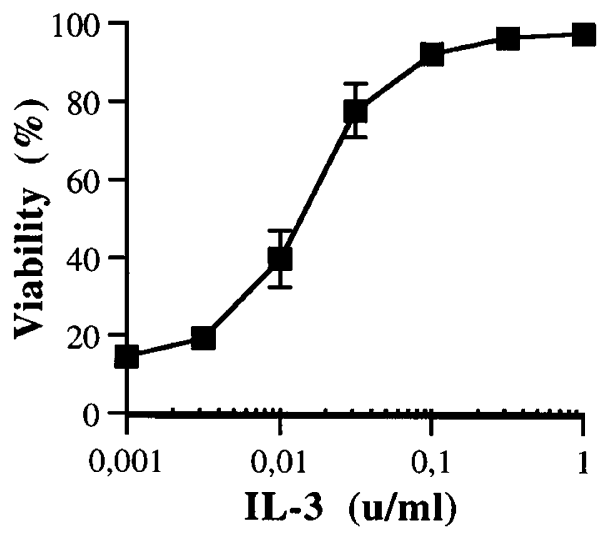

B

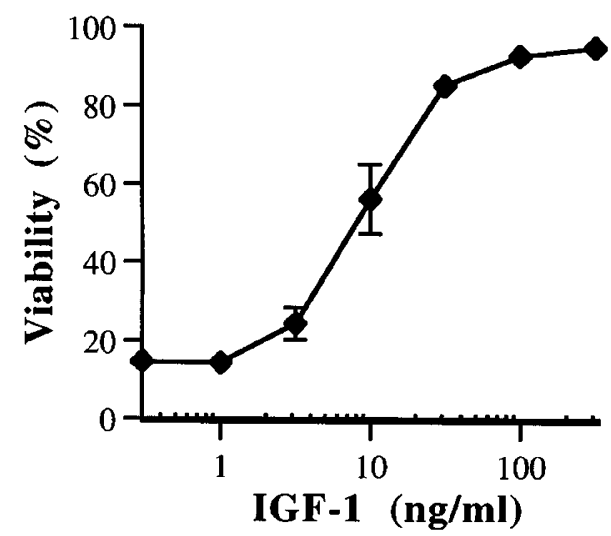

Figure 1 IL-3 and IGF-1 inhibit apoptosis in Baf-3 cells. Baf-3 cells were washed and cultured in the presence of different concentrations of IL-3 (A) or IGF-1 (B) for $20 \mathrm{~h}$. Viability was measured by propidium iodide exclusion. Data are presented as mean viability \pm S.D. of four independent experiments 
cells induced by IL-3 was not significantly affected by similar doses of LY294002 (Figure 3A and C). This could result from a lack of PI3-kinase inhibition by LY294002 in cells stimulated by IL-3. However, since LY294002 did inhibit both IGF-1 and IL-3 mediated induction of $\mathrm{Bcl}-\mathrm{X}$ mRNA such an interpretation appears unlikely (Figure 2). These results indicate that IL-3 activates yet another survival pathway which is independent of PI3-kinase activation.

\section{PI3-kinase is involved in IGF-1 but not IL-3 mediated inhibition of caspases activation or activity}

To identify mechanisms involved in growth factor dependent rescue of Baf-3 cells we have investigated the regulation of caspases activity following IGF-1 or IL-3 readdition. We first determined which caspases are activated following IL-3 starvation. Fluorogenic tetrapeptides which allow detection of different sub-groups of caspases were used, DEVD-AMC which is recognized by caspase 3, 7 and 8, VEID-AMC by caspase 6 and 8 and WEHD-AMC by caspase 1,4 and $5^{32}$ Cells were starved of IL-3 for different times and cell lysates were incubated with the fluorogenic caspase substrates. The percentage of apoptotic cells in the cultures was measured for each time point using propidium iodide exclusion. Data in Figure 4 show that following IL-3 starvation, there is a time-dependent increase in caspase activity resulting in the cleavage of DEVD-AMC or VEIDAMC. In contrast, no significant cleavage of WEHD-AMC could be detected $22 \mathrm{~h}$ after IL-3 removal (Figure 4B). The caspase activity present in the cell lysates was inhibited by the addition of the inhibitor DEVD-CHO (data not shown). Since caspase 6 is not inhibited by DEVD$\mathrm{CHO}$, these results indicate that the caspase activity includes caspase 3,7 and 8 . In Baf-3 cells, the maximum caspase activity is reached $9-10 \mathrm{~h}$ following IL-3 starvation. At that time, approximately $70 \%$ of the cells can be rescued by growth factor readdition. As shown in Figure 4C addition of IL-3 or IGF-1 to growth factor deprived Baf-3 cells is accompanied by a decrease
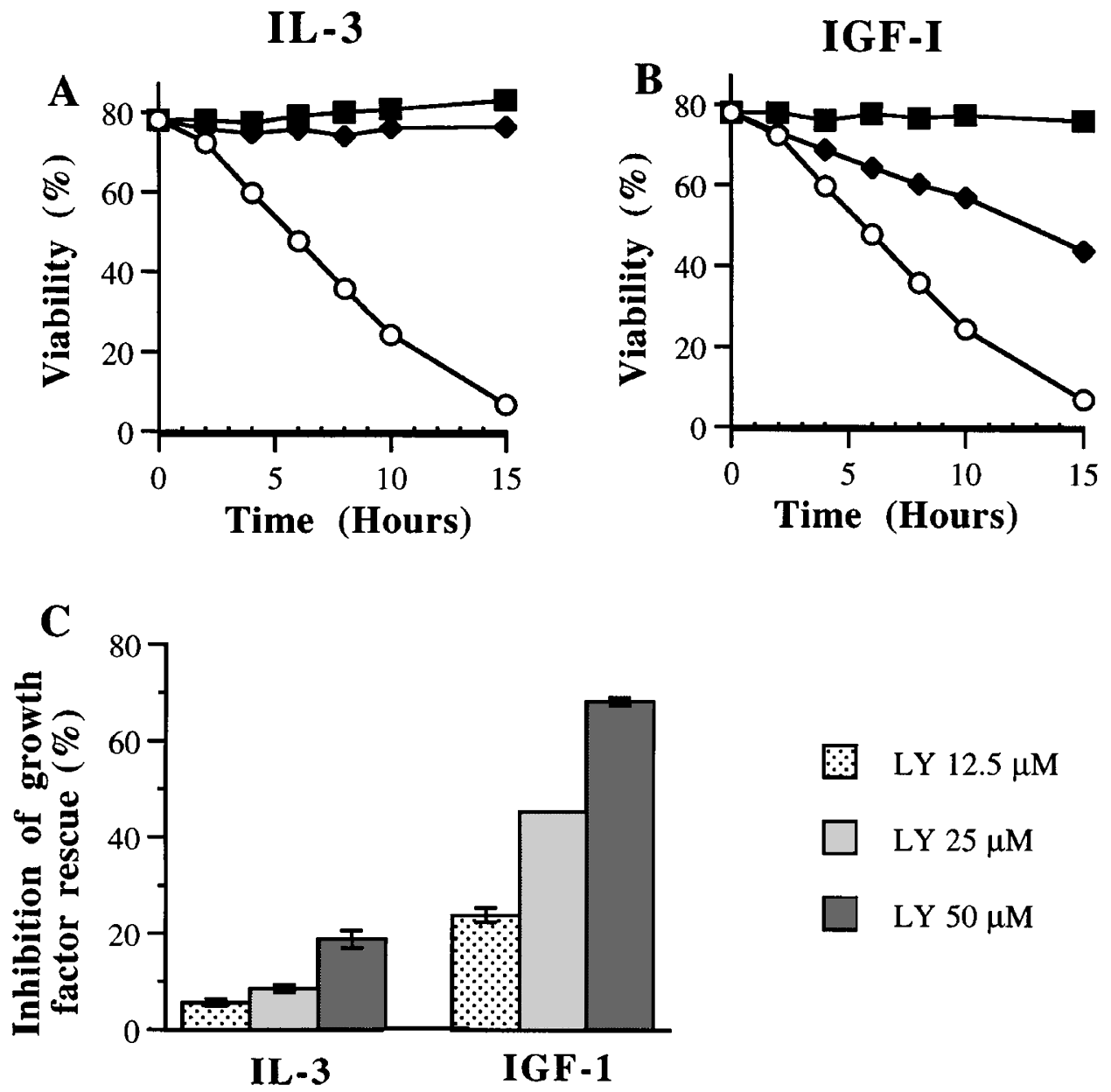

Figure 3 Inhibition of apoptosis by IGF-1 but not IL-3 is dependent on PI3-kinase activation. Baf-3 cells were starved of IL-3 for $9 \mathrm{~h}$. (A,B) no growth factors (O), growth factors in the absence $(\mathbf{\square})$ or in the presence $(\bullet)$ of $25 \mu \mathrm{M}$ LY294002 were added back. Growth factors used were IL-3 (A) and IGF-1 (B). LY294002 was pre-incubated for $15 \mathrm{~min}$ before the addition of growth factors. (C) Growth factors were added back in the presence of different concentrations of LY294002 $(12.5 \mu \mathrm{M}, 25 \mu \mathrm{M}$ and $50 \mu \mathrm{M})$ and viability was measured $15 \mathrm{~h}$ later. Data show mean values \pm S.D. of triplicate samples. Results are representative of four independent experiments 
in the level of caspase activity measured in cell lysate. As we have been unable to measure caspase activity in single cells, we do not know if the caspase activity we detect corresponds only to apoptotic cells or if caspase activation occurs in life cells not yet committed to apoptosis and which can be rescued by IL-3. Hence we do not know if in vivo IL-3 acts to inhibit caspase activation or caspase activity. In these cells, the inhibition of PI3-kinase by LY294002 partially inhibits the effects of IGF-1 but not those of IL-3 on caspase activity measured in cell lysate. These results confirm that PI3-kinase is involved in the inhibition of apoptosis by IGF-1. In addition, they show that IL-3 couples to a PI3-kinase independent pathway which regulates caspases.

\section{Inhibition of caspase activation is not sufficient to induce survival of Baf-3 cells in the absence of growth factors}

In some experimental systems inhibition of caspases promotes cell survival. ${ }^{9}$ In order to determine whether a similar effect could be detected in IL-3 starved Baf-3 cells, we have used the caspase inhibitor zVAD-fmk. This compound is a multispecific caspase inhibitor which completely inhibits the cleavage of DEVD-AMC in IL-3 starved Baf-3 cell lysates (data not shown). Results presented in Figure 5 show that zVAD-fmk added to Baf3 cells starved of IL-3 for $9 \mathrm{~h}$ at concentrations of 500 and $1000 \mu \mathrm{M}$ was able to inhibit apoptosis as measured by
A

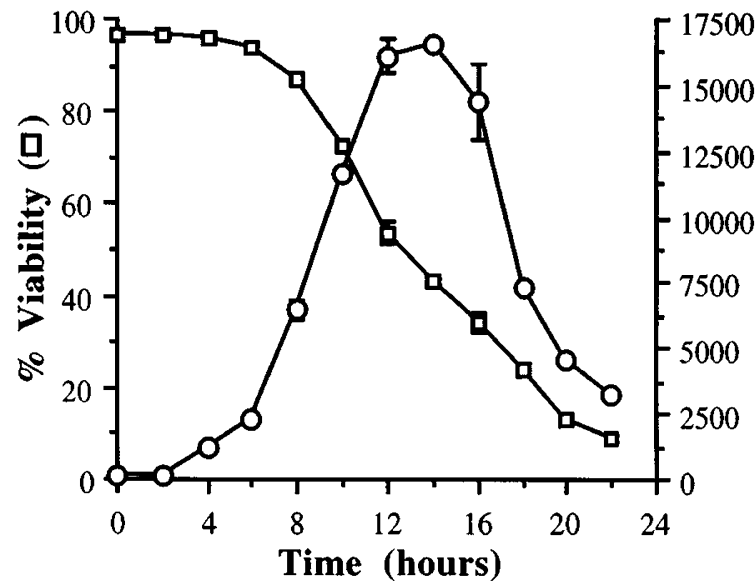

C

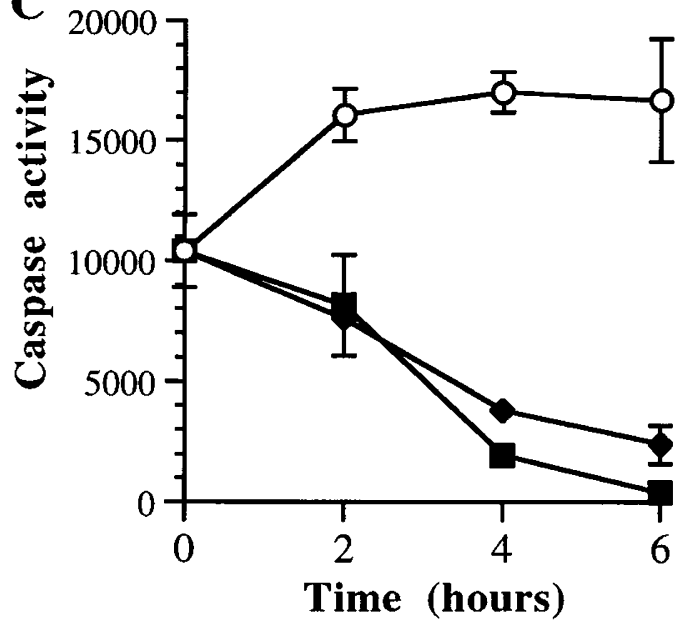

B

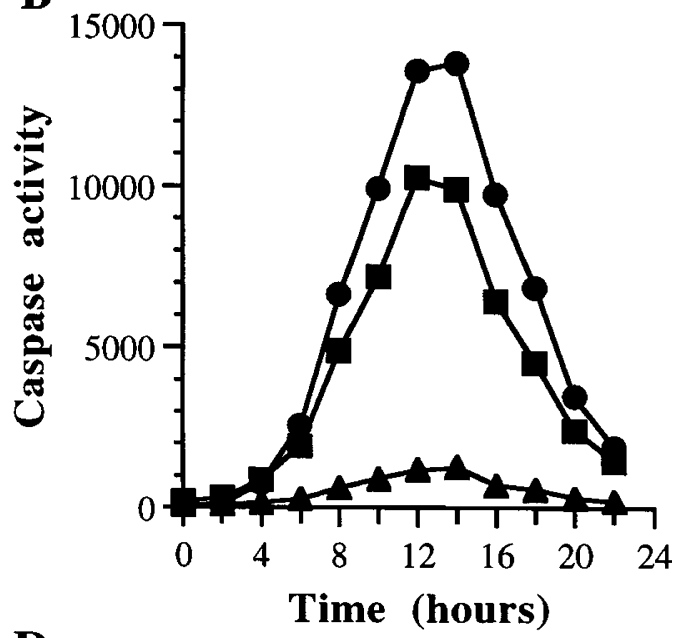

D

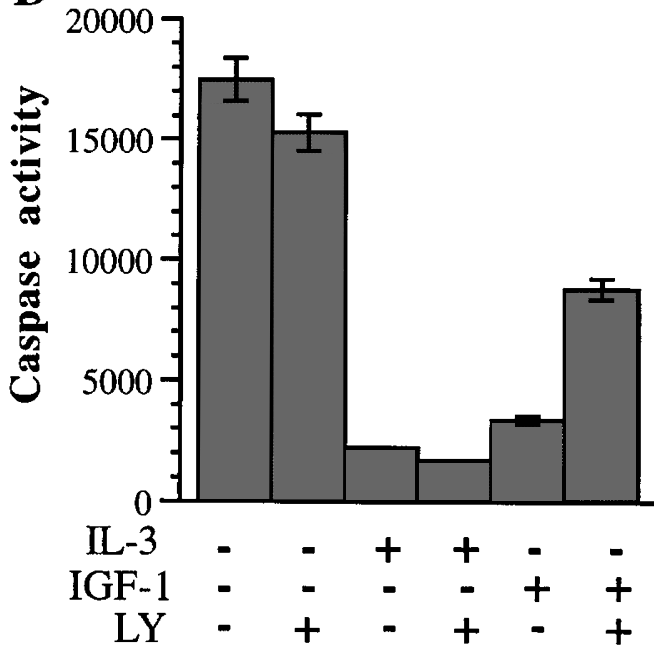

Figure 4 Induction of apoptosis and caspases activation following IL-3 starvation. (A) Baf-3 cells were starved of IL-3 and, at the indicated times, the percentages of viable cells were measured by propidium iodide exclusion ( $\square$ ) and DEVD-AMC cleavage activity in lysates (O) was measured. Data are presented as mean values \pm S.D. of triplicate samples. (B) Caspase activity was tested on three different peptide substrates DEVD-AMC (O), VEID-AMC ( $\mathbf{\square})$ or WEHD-AMC $(\mathbf{A})$. (C) Inhibition of caspases activity by IL-3 and IGF-1. Baf-3 cells were starved of IL-3 for $9 \mathrm{~h}$ and no growth factors (O), IL-3 ( $\mathbf{D}$ ) or IGF-1 ( $\bullet$ ) were added back. DEVDAMC cleavage activity in lysates was measured $0,2,4$ and $6 \mathrm{~h}$ later. Data are presented as mean values of triplicates \pm S.D. in two independent experiments. (D) Regulation of caspases activity by IGF-1 but not IL-3 is inhibited by LY294002. Baf-3 cells were starved of IL-3 for $9 \mathrm{~h}$ and no growth factor, IL-3 or IGF-1 were added in the presence or absence of LY294002. LY294002 (25 $\mu \mathrm{M})$ was pre-incubated for 15 min before stimulation with growth factors. After $4 \mathrm{~h}$, DEVD-AMC cleavage activity was measured in cell lysates. Data are presented as mean values of triplicate samples \pm S.D. Results are representative of at least three independent experiments 


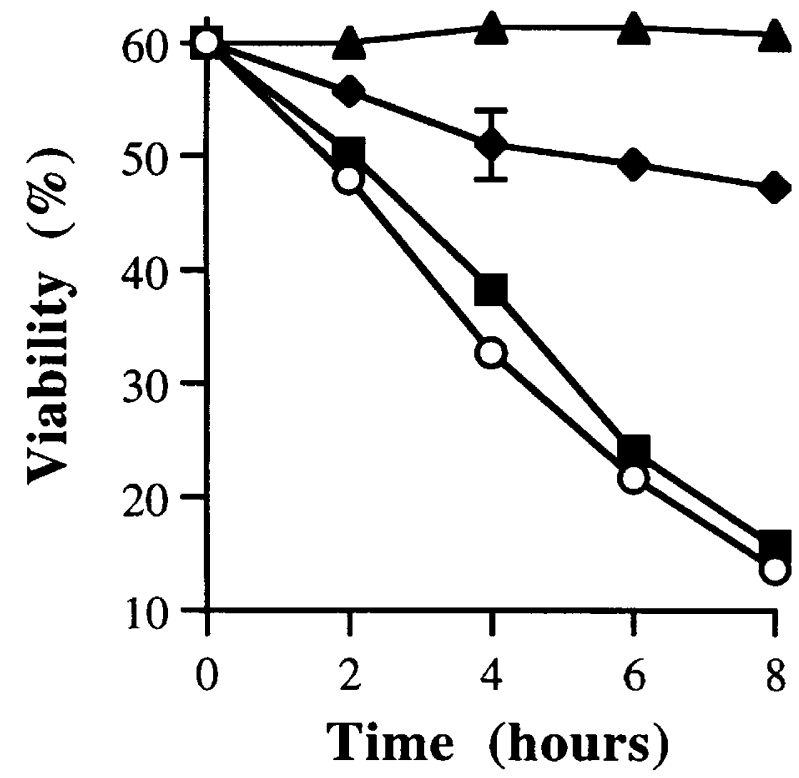

Figure 5 zVAD-fmk delays apoptosis. Different concentrations of zVAD-fmk were added on cells starved of growth factors for $9 \mathrm{~h}$ and viability was determined by propidium iodide exclusion at the indicated times. Concentrations used were $0 \mu \mathrm{M}(\bigcirc), 250 \mu \mathrm{M}(\boldsymbol{\square}), 500 \mu \mathrm{M}(\bullet)$ and $1000 \mu \mathrm{M}(\mathbf{\Delta})$. Data are presented as mean viability in triplicate samples \pm S.D. One representative experiment out of three is shown

propidium iodide exclusion. In Baf-3 cells relatively high doses of zVAD-fmk are necessary to inhibit the apoptosis induced by IL-3 starvation. This inhibition was specific as zYVAD-fmk a caspase 1 inhibitor was not able to inhibit the apoptosis of Baf-3 cells at similar concentrations (data not shown). Moreover similar concentrations were necessary to inhibit the cleavage of PARP in Baf-3 cells following IL-3 removal. ${ }^{33}$ However, in some systems caspase inhibition only delays the appearance of the apoptotic phenotype. $^{10}$ We therefore measured the ability of Baf-3 cells to form clones following different culture conditions. Cells were grown in the presence or absence of IL-3, with or without $600 \mu \mathrm{M}$ zVAD-fmk. After $20 \mathrm{~h}$ cell viability was measured by propidium iodide exclusion and cells were cloned in the presence of IL-3 by limiting dilution. The cloning efficiency was measured 10 days later. Results presented in Table 1 show that after $20 \mathrm{~h}$ culture in the absence of IL-3, $16 \%$ of Baf-3 cells are viable and $70 \%$ of those are able to form clones when IL-3 is added back to the culture. This is comparable to the cloning efficiency obtained for control cells maintained in IL-3. In contrast when zVAD-fmk is present during the $\mathrm{IL}-3$ starvation period, more than $70 \%$ of Baf-3 cells are apparently viable but, only $3.6 \%$ of these cells are capable of giving rise to a clone when IL-3 is added back to the culture. Overexpression of $\mathrm{Bcl}-\mathrm{X}$ which is located upstream of caspases activation, leads to increased survival in the absence of growth factors since $80 \%$ of these cells retain their ability to form a clone. These results indicate that the irreversible commitment to cell death which follows IL-3 starvation in Baf-3 cells precedes the activation of caspases inhibited by zVAD-fmk.
Table 1 zVAD-fmk does not inhibit cell death of IL-3 starved cells

\begin{tabular}{lcccc}
\hline & & \multicolumn{3}{c}{ Clonable cells (\%) } \\
& n & Viability (\%) & A & B \\
\hline IL-3 & 3 & $96.8 \pm 0.4$ & $60 \pm 34$ & 62 \\
IL-3+zVAD-fmk & 3 & $96.7 \pm 0.6$ & $69.7 \pm 49$ & 72 \\
no IL-3 & 6 & $15.2 \pm 3.9$ & $11.4 \pm 5.7$ & 75 \\
no IL-3+DMSO & 3 & $16.0 \pm 6.5$ & $11.1 \pm 6.6$ & 70 \\
no IL-3+ZVAD-fmk & 6 & $71.7 \pm 7.9$ & $2.6 \pm 1.7$ & 3.6 \\
IL-3+Bcl-X & 3 & $96.3 \pm 2$ & $66.3 \pm 39$ & 69 \\
no IL-3+Bcl-X & 3 & $92.3 \pm 0.6$ & $74 \pm 37$ & 80 \\
\hline
\end{tabular}

Baf-3 cells were cultured for $20 \mathrm{~h}$ with or without IL-3 in the presence or absence of zVAD-fmk $600 \mu \mathrm{M}$. Baf-3 cells overexpressing the $b c l-X$ gene were grown for $20 \mathrm{~h}$ with or without IL-3. Percentage viability was determined by propidium iodide exclusion at the end of a $20 \mathrm{~h}$ incubation time. Limiting dilutions were performed as described in Materials and Methods. Viability and cloning efficiency values are presented as mean \pm S.D. of $n$ independent experiments performed. (A) percentage of the total starting population capable of forming a clone upon restimulation with IL-3. (B) cloning efficiency corresponding to the percentage of viable cells at the end of the $20 \mathrm{~h}$ incubation time capable of forming a clone upon restimulation with IL-3. This number was calculated by dividing the cloning effciency (A) by the viability estimated using propidium iodide exclusion

\section{Discussion}

In this study we have shown that the regulation of $\mathrm{Bcl}-\mathrm{X}$ by IL3 or IGF-1 is dependent on the activation of PI3-kinase. Indeed, the increase in $\mathrm{Bcl}-\mathrm{X}$ mRNA levels which is observed in Baf-3 cells following stimulation by IL-3 or IGF-1 is inhibited in the presence of compounds which block PI3-kinase activity. This enzyme has also been implicated in the induction of $\mathrm{Bcl}-$ $X$ by IL-2 and CD28. ${ }^{34,35}$ The residual Bcl-X mRNA induction observed in the presence of PI3-kinase inhibitors involves MAP-kinase activation. Indeed, we have shown that inhibition of MAP-kinase activation also resulted in decreased $\mathrm{Bcl}-\mathrm{X}$ mRNA induction. ${ }^{29}$ Moreover, Bcl-X mRNA induction by IL-3 is abrogated when both PI3-kinase and MAP-kinase are inhibited. (Personal communication).

It has been shown that PI3-kinase activates AKT inducing the phosphorylation and the inactivation of the pro-apoptotic $\mathrm{Bcl}-\mathrm{X}_{\mathrm{L}}$ regulator, Bad. ${ }^{23}$ Hence, PI3-kinase would control $\mathrm{Bcl}-\mathrm{X}$ not only at the transcriptional level but also at the post-translational level. We have previously shown that the upregulation of $B c l-X_{L}$ is not necessary for the short term inhibition of apoptosis by IL-3 or IGF-1, indicating that post-transcriptional modifications of preexisting cellular proteins are sufficient for short-term survival. $^{29}$ In order to determine if the pathways downstream of PI3-kinase are solely responsible for these modifications, we have measured the impact of PI3-kinase on the survival induced by IL-3 or IGF-1. We have found that the inhibition of PI3-kinase results in decreased Baf-3 survival in response to IGF-1. This is in agreement with previous reports indicating that the activation of the PI3kinase/AKT pathway is both necessary and sufficient for the induction of survival by IGF-1 in different cell types. ${ }^{28,30,31}$ In contrast, survival induced by IL-3 was not significantly affected by the inhibition of PI3-kinase. This is not due to a lack of PI3-kinase inhibition since similar concentration of LY294002 induced a strong decrease in the level of $\mathrm{Bcl}-\mathrm{X}$ mRNA in response to IGF-1 or IL-3. 
Moreover, in other hematopoietic cells, similar doses of LY294002 and wortmannin were shown to completely inhibit PI3-kinase activation ${ }^{36,37}$ and the phosphorylation of Bad induced by IL-3. ${ }^{36}$ Hence, these results suggest that IL-3 but not IGF-1 activates a PI3-kinase independent pathway which is sufficient to inhibit apoptosis in Baf-3 cells. How IL-3 inhibits cell death in absence of PI3-kinase activation is not clear. However, it has been shown that IL-3 inhibits apoptosis via a PKC dependent pathway which could be responsible of $\mathrm{Bcl}-2$ phosphorylation. ${ }^{38}$ These results were confirmed by measuring the inhibition of caspases activation by IL-3 and IGF-1. Indeed, the inhibition of caspases activation by IGF-1 but not IL-3 was dependent on the activity of PI3-kinase.

Caspases activation is an early event in the apoptotic process. In most systems, caspases inhibition was shown to inhibit or delay the appearance of apoptotic cells. However, the long-term viability of cells has only been studied in some experimental systems. In some of these, caspases activation precedes the point of irreversible commitment to death and their inhibition leads to increased survival. This is the case for Fas induced apoptosis where inhibition of caspases with zVAD-fmk or zDEVD-fmk leads to increased survival. ${ }^{9}$ Similar results have also been obtained in vivo using the viral caspases inhibitor p35. ${ }^{39,40}$ In contrast, in cells overexpressing cMyc, commitment to death following growth-factor starvation is independent of the caspases activities inhibited by zVAD-fmk. ${ }^{10}$ In this study, we show that the addition of zVAD-fmk to IL-3 starved Baf-3 cells delays the onset of apoptosis as measured by propidium iodide incorporation. However, in contrast to cells rescued by IL-3, cells rescued by this caspases inhibitor are irreversibly committed to death. Indeed, only $3.6 \%$ of these cells were able to grow and form colonies following growth factor readdition while more than $70 \%$ of control cells were rescued by IL-3. Hence, in Baf-3 cells commitment to death is either independent of caspase activation or, alternatively some caspases which are activated following growth-factor starvation are not inhibited by zVAD-fmk. These would correspond to caspases with different substrate specificities as zVAD-fmk inhibits the cleavage of the three peptide substrates we have used (data not shown). Together these results suggest that the signal transduction pathways involved in the inhibition of apoptosis by IL-3 or IGF-1 act upstream of caspases activation.

\section{Materials and Methods}

\section{Cell culture and reagents}

The bone marrow derived IL-3 dependent Baf-3 cells ${ }^{41}$ were maintained in DMEM containing $6 \%$ foetal calf serum (Boehringer Mannheim), $2 \mathrm{mM} \mathrm{L-glutamine} \mathrm{(Gibco} \mathrm{BRL)} \mathrm{and} \mathrm{5 \%} \mathrm{WEHI} \mathrm{3B} \mathrm{cell-}$ conditioned medium as a source of IL-3. Cells were grown at a density of $5 \times 10^{4}$ to $5 \times 10^{5}$ per $\mathrm{ml}$. To remove IL-3, cells were washed twice in DMEM/FCS 6\%. Baf-3 cells overexpressing Bcl-X clone (Baf-Bcl-X-4) have been described elsewhere. ${ }^{42}$
Wortmannin (1 mM, Sigma), LY294002 (20 mM, Calbiochem) and zVAD-fmk (z-Val-Ala-DL-Asp-fluoromethylketone $100 \mathrm{mM}$, Bachem) were resuspended in DMSO (Sigma). Murine IL-3 and human IGF-1 were obtained from PeproTech. These growth factors are able to maintain viability in a concentration dependent fashion (Figure 1). For all experiments IL-3 and IGF-1 were used at a concentration giving maximal Baf-3 viability after $20 \mathrm{~h}$ in culture (i.e. $1 \mathrm{U} / \mathrm{ml}$ and $300 \mathrm{ng} / \mathrm{ml}$ respectively). This concentration of IGF-1 is comparable to the one used to protect against UV-B ${ }^{31}$ or $\mathrm{C}-M y c$ induced apoptosis. $^{43}$

\section{Measurement of apoptosis}

As in Baf-3 cells detection of apoptotic cells with propidium iodide, annexin V or DioC6 staining gives similar results (data not shown), apoptotic and dead cells were detected by propidium iodide staining. $5 \times 10^{3}$ to $10^{4}$ cells were incubated a few minutes with propidium iodide (Sigma) at a concentration of $5 \mu \mathrm{g} / \mathrm{ml}$. For each sample, 5000 cells were counted on a FacScan (Becton-dickinson) and analyzed on FSC/FL2 dot plot using the CellQuest software. This staining protocol allows the distinction between dead (FL-2 bright, FSC low), apoptotic (FL2 dull, FSC intermediate) and live cells (FL-2 negative, FSC high). The percentage of viable cells correspond to the percentage of FL-2 negative cells.

\section{Cleavage of fluorogenic substrate}

$2.5 \times 10^{7}$ cells were washed in PBS and lysed for $15 \mathrm{~min}$ on ice in $1 \mathrm{ml}$ lysis buffer (10 mM HEPES, pH 7.4, $250 \mathrm{mM}$ sucrose, $2 \mathrm{mM}$ EDTA, $0.1 \%$ CHAPS, $5 \mathrm{mM}$ dithiothreitol, $1 \mathrm{mM}$ phenylmethylsulfonyl fluoride, $10 \mu \mathrm{g} / \mathrm{ml}$ pepstatin, $10 \mu \mathrm{g} / \mathrm{ml}$ leupeptin and $5 \mu \mathrm{g} / \mathrm{ml}$ aprotinin). Lysates were centrifuged at $12000 \times \mathrm{g}$ for $15 \mathrm{~min}$ at $4^{\circ} \mathrm{C}$ and the supernatant was stored at $-20^{\circ} \mathrm{C}$. Caspase activity was measured by incubating $50 \mu \mathrm{l}$ of supernatant with $50 \mu \mathrm{l}$ of lysis buffer containing $400 \mu \mathrm{M}$ DEVD-AMC or VEID$A M C$ or WEHD-AMC (Bachem) for $40 \mathrm{~min}$ at $37^{\circ} \mathrm{C}$. Cleavage of the caspase substrate was detected by using a Fluoroskan II (Labsystems) fluorimeter (emission at $460 \mathrm{~nm}$, excitation at $355 \mathrm{~nm})$.

\section{Limiting dilution analysis}

The cloning efficiency was determined by limiting dilution. $5 \times 10^{5}$ cells treated for $20 \mathrm{~h}$ were diluted in medium containing IL-3. For each cell dilution, 48 wells were seeded with numbers of cells ranging from $10^{3}$ to 0.1 cells/well. Ten days later, the number of wells containing a clone was scored. The cloning efficiency was calculated using the Poisson distribution.

\section{Acknowledgements}

Yann Leverrier, Joëlle Thomas and Anne-Laure Mathieu are supported by fellowships from the Ligue Nationale Contre le Cancer, the Fondation Marcel Mérieux and the Centre Nationale de la Recherche Scientifique respectively. This work was supported by institutional grants from the Centre Nationale de la Recherche Scientifique and the Ministère de l'Enseignement Supérieur et de la Recherche and by additional support from the Association pour la Recherche sur le Cancer, the Région RhôneAlpes and the Comité Départemental (Rhône and Saône et Loire) de la Ligue Nationale Française contre le Cancer. 


\section{References}

1. Raff MC, Barres BA, Burne JF, Coles HS, Ishizaki Y and Jacobson MD (1993) Programmed cell death and the control of cell survival: lessons from the nervous system. Science 262: 695-700

2. Hannun YA (1997) Apoptosis and the dilemma of cancer chemotherapy. Blood 89: $1845-1853$

3. Cohen GM (1997)Caspases: the executioners of apoptosis. Biochem. J. 326:116

4. Nicholson DW and Thornberry NA (1997) Caspases: killer proteases. Trends Biochem. Sci. 22: 299-306

5. Boldin MP, Goncharov TM, Goltsev YV and Wallach D (1996) Involvement of $\mathrm{MACH}$, a novel MORT1/FADD-interacting protease, in Fas/APO-1- and TNF receptor-induced cell death. Cell 85: 803-815

6. Enari M, Talanian RV, Wong WW and Nagata S (1996) Sequential activation of ICE-like and CPP32-like proteases during Fas-mediated apoptosis. Nature 380: 723-726

7. Muzio M, Chinnaiyan AM, Kischkel FC, O'Rourke K, Shevchenko A, Ni J, Scaffidi C, Bretz JD, Zhang M, Gentz R, Mann M, Krammer PH, Peter ME and Dixit VM (1996) FLICE, a novel FADD-homologous ICE/CED-3-like protease, is recruited to the CD95 (Fas/APO-1) death-inducing signaling complex. Cell 85: 817-827

8. Srinivasula SM, Ahmad M, Fernandes-Alnemri T, Litwack $G$ and Alnemri ES (1996) Molecular ordering of the Fas-apoptotic pathway: The Fas/APO-1 protease Mch5 is a CrmA-inhibitable protease that activates multiple Ced-3/ICElike cysteine proteases. Proc. Natl. Acad. Sci. USA 93: 14486-14491

9. Longthorne VL and Williams GT (1997) Caspase activity is required for commitment to Fas-mediated apoptosis. EMBO J. 16: 3805-3812

10. McCarthy NJ, Whyte MK, Gilbert CS and Evan GI (1997) Inhibition of Ced-3/ICErelated proteases does not prevent cell death induced by oncogenes, DNA damage, or the Bcl-2 homologue Bak. J. Cell. Biol. 136: 215-227

11. Zou H, Henzel WJ, Liu X, Lutschg A and Wang X (1997) Apaf-1, a human protein homologous to $C$. elegans CED-4, participates in cytochrome c-dependent activation of caspase-3. Cell 90: 405-413

12. Chinnaiyan AM, Chaudhary D, O'Rourk K, Koonin EV and Dixit VM (1997) Role of CED-4 in the activation of CED-3. Nature 388: 728-729

13. Chinnaiyan AM, O'Rourke K, Lane BR and Dixit VM (1997) Interaction of CED-4 with CED-3 and CED-9: a molecular framework for cell death. Science 275 : $1122-1126$

14. LiP, Nijhawan D, Budihardjo I, Srinivasula SM, Ahmad M, Alnemri ES and Wang X (1997) Cytochrome $c$ and dATP-dependent formation of Apaf-1/caspase-9 complex initiates an apoptotic protease cascade. Cell 91: 479-489

15. Reed JC (1997) Double identity for proteins of the Bcl-2 family. Nature 387: $773-$ 776

16. Minn AJ, Velez P, Schendel SL, Liang H, Muchmore SW, Fesik SW, Fill M and Thompson CB (1997) Bcl-xL forms an ion channel in synthetic lipid membranes. Nature 385: 353-357

17. Schendel SL, Xie Z, Montal MO, Matsuyama S, Montal M and Reed JC (1997) Channel formation by antiapoptotic protein Bcl-2. Proc. Natl. Acad. Sci. USA 94: 5113-5118

18. Susin SA, Zamzami N, Castedo M, Hirsch T, Marchetti P, Macho A, Daugas E, Geuskens M and Kroemer G (1996) Bcl-2 inhibits the mitochondrial release of an apoptogenic protease. J. Exp. Med. 184: 1331-1341

19. Vander Heiden MG, Chandel NS, Williamson EK, Schumacker PT and Thompson CB (1997) Bcl-xL regulates the membrane potential and volume homeostasis of mitochondria. Cell 91:627-637

20. Wang HG, Rapp UR and Reed JC (1996) Bcl-2 targets the protein kinase Raf-1 to mitochondria. Cell 87: 629-638

21. Ahmed NN, Grimes HL, Bellacosa A, Chan TO and Tsichlis PN (1997) Transduction of interleukin-2 antiapoptotic and proliferative signals via Akt protein kinase. Proc. Natl. Acad. Sci. USA 94: 3627-3632

22. Franke TF, Kaplan DR and Cantley LC (1997) PI3K: downstream AKTion blocks apoptosis. Cell 88: 435-437

23. Datta SR, Dudek H, Tao X, Masters S, Fu H, Gotoh Y and Greenberg ME (1997) Akt phosphorylation of BAD couples survival signals to the cell-intrinsic death machinery. Cell 91: $231-241$
24. Zha J, Harada H, Yang E, Jockel J and Korsmeyer SJ (1996) Serine phosphorylation of death agonist BAD in response to survival factor results in binding to 14-3-3 not BCL-XL. Cell 87: 619-628

25. Diaz-Meco MT, Municio MM, Frutos S, Sanchez P, Lozano J, Sanz L and Moscat $J$ (1996) The product of par-4, a gene induced during apoptosis, interacts selectively with the atypical isoforms of protein kinase C. Cell 86: 777-786

26. Fukada T, Hibi M, Yamanaka Y, Takahashi-Tezuka M, Fujitani Y, Yamaguchi T, Nakajima K and Hirano T (1996) Two signals are necessary for cell proliferation induced by a cytokine receptor gp130: involvement of STAT3 in anti-apoptosis. Immunity 5: 449-460

27. Gotoh N, Tojo A and Shibuya M (1996) A novel pathway from phosphorylation of tyrosine residues $239 / 240$ of Shc, contributing to suppress apoptosis by IL-3. EMBO J. 15: 6197-6204

28. Kinoshita T, Yokota T, Arai K and Miyajima A (1995) Suppression of apoptotic death in hematopoietic cells by signalling through the IL-3/GM-CSF receptors. EMBO J. 14: 266-275

29. Leverrier Y, Thomas J, Perkins GR, Mangeney M, Collins MK and Marvel J (1997) In bone marrow derived Baf-3 cells, inhibition of apoptosis by IL-3 is mediated by two independent pathways. Oncogene 14: 425-430

30. Dudek H, Datta SR, Franke TF, Birnbaum MJ, Yao R, Cooper GM, Segal RA, Kaplan DR and Greenberg ME (1997) Regulation of neuronal survival by the serine-threonine protein kinase Akt. Science 275: 661-665

31. Kulik G, Klippel A and Weber MJ (1997) Antiapoptotic signalling by the insulinlike growth factor I receptor, phosphatidylinositol 3-kinase, and Akt. Mol. Cell. Biol. 17: 1595-1606

32. Thornberry NA, Rano TA, Peterson EP, Rasper DM, Timkey T, Garcia-Calvo M, Houtzager VM, Nordstrom PA, Roy S, Vaillancourt JP, Chapman KT and Nicholson DW (1997) A combinatorial approach defines specificities of members of the caspase family and granzyme B. Functional relationships established for key mediators of apoptosis. J. Biol. Chem. 272: 17907-17911

33. Furlong IJ, Ascaso R, Lopez Rivas A and Collins MK (1997) Intracellular acidification induces apoptosis by stimulating ICE-like protease activity. J. Cell Sci. 110: 653-661

34. Collette Y, Razanajaona D, Ghiotto M and Olive D (1997) CD28 can promote T cell survival through a phosphatidylinositol 3- kinase-independent mechanism. Eur. J. Immunol. 27: 3283-3289

35. Gonzalez-Garcia A, Merida I, Martinez AC and Carrera AC (1997) Intermediate affinity interleukin-2 receptor mediates survival via a phosphatidylinositol 3kinase-dependent pathway. J. Biol. Chem. 272: 10220-10226

36. del Peso L, Gonzalez-Garcia M, Page C, Herrera R and Nunez G (1997) Interleukin-3-induced phosphorylation of BAD through the protein kinase Akt. Science 278: $687-689$

37. Minshall C, Arkins S, Freund GG and Kelley KW (1996) Requirement for phosphatidylinositol $3^{\prime}$-kinase to protect hemopoietic progenitors against apoptosis depends upon the extracellular survival factor. J. Immunol. 156: $939-947$

38. Ito T, Deng X, Carr B and May WS (1997) Bcl-2 phosphorylation required for antiapoptosis function. J. Biol. Chem. 272: 11671-11673

39. Sugimoto A, Friesen PD and Rothman JH (1994) Baculovirus p35 prevents developmentally programmed cell death and rescues a ced-9 mutant in the nematode Caenorhabditis elegans. EMBO J. 13: 2023-2028

40. White K, Tahaoglu E and Steller H (1996) Cell killing by the Drosophila gene reaper. Science 271: 805-807

41. Rodriguez-Tarduchy G, Collins M and Lopez-Rivas A (1990) Regulation of apoptosis in interleukin-3-dependent hemopoietic cells by interleukin-3 and calcium ionophores. EMBO J. 9: 2997-3002

42. Thomas J, Leverrier $Y$ and Marvel J (1998) Bcl-X is the major pleiotropic antiapoptotic gene activated by retroviral insertion mutagenesis in an IL-3 dependent bone marrow derived cell line. Oncogene 16: 1399-1408

43. Harrington EA, Bennett MR, Fanidi A and Evan GI (1994) c-Myc-induced apoptosis in fibroblasts is inhibited by specific cytokines. EMBO J. 13: 32863295 